\title{
Emancypacja jako nowy nurt rehabilitacji
}

ABSTRACT: Joanna Konarska, Emancypacja jako nowy nurt rehabilitacji [Emancipation as a new trend rehabilitation]. Interdyscyplinarne Konteksty Pedagogiki Specjalnej, nr 10, Poznań 2015. Pp. 51-71. Adam Mickiewicz University Press. ISSN 2300-391X

The article contains reflections on the essence of emancipation, conditions and opportunities for its realization to people with disabilities. The topic of discussion is undertaken formation by parents, teachers and other persons involved in the rehabilitation process of such personality traits that facilitate self-realization and autonomy. The ability to achieve self-realization is a form of emancipation. Taken at the end of the discussion about the legitimacy of multiplication terms.

KEY WORDS: emancipation, rehabilitation, self-fulfilment, independence, autonomy

Problematyka niepełnosprawności wiąże się z wielostronnymi, wielodyscyplinarnymi i bardzo rozciągniętymi w czasie działaniami, w których koordynacja i kierunkowość wynikająca z długodystansowej perspektywy ujmowania tych zagadnień jest zadaniem kluczowym.

Obok takich pojęć jak integracja i inkluzja coraz częściej pojawiają się próby jeszcze lepszego uszczegółowienia terminu oddającego intencje tych, którym los osób z niepełnosprawnością nie jest obojętny i którzy czynią starania o to, by osoby z niepełnosprawnością zajmowały w społeczeństwie takie miejsce, jakie jest zgodne 
z ich wykształceniem, kompetencjami zawodowymi i predyspozycjami osobowościowymi.

Czy termin „emancypacja” oddaje istotę zadań i problemów, które dotyczą zarówno samego procesu rehabilitacji, jak i funkcjonowania człowieka z niepełnosprawnością w społeczeństwie?

Oczywiście, są to rozważania czysto teoretyczne, które na tym etapie nie przynoszą niczego nowego dla samych osób z niepełnosprawnością, ale właśnie od pełnego dookreślenia wszystkich terminów, którymi posługują się specjaliści zaangażowani $\mathrm{w}$ proces rehabilitacji, zależy powodzenie wszelkich praktycznych działań skierowanych na konkretne osoby. Istniejąca obecnie wielorakość i wieloznaczność używanej potocznie i w nauce terminologii związanej z osobami niepełnosprawnymi i procesem ich usprawniania wnosi bardzo wiele chaosu i wymaga uporządkowania, więc wprowadzenie każdego nowego terminu musi być poddane pod rozwagę pod kątem jego zasadności i komplementarności $\mathrm{w}$ stosunku do terminów pochodnych, a już istniejących w interdyscyplinarnym języku naukowców i praktyków.

Czym wobec tego jest "emancypacja” i w jakich relacjach ten termin pozostaje w stosunku do dwóch pokrewnych: „integracja” i ,inkluzja"?.

Termin „emancypacja” pochodzi z prawa rzymskiego i pierwotnie oznaczał uwolnienie spod władzy rodzicielskiej (ojcowskiej), co skutkowało wygaśnięciem władzy ojcowskiej w stosunku do emancypowanego, utratą statusu rodzinnego, ale także wyposażeniem $\mathrm{w}$ majątek przekazany emancypowanemu w zarządzanie ${ }^{1}$. Prawo to dotyczyło potomków płci męskiej, bo wobec dziewcząt postępowano inaczej i zapewne ta wielowiekowa dyskryminacja doprowadziła pod koniec XVIII i w XIX w. do nasilonego międzynarodowego ruchu emancypacyjnego zorganizowanych związków kobiet. Warto przy tym zauważyć, że chociaż roszczenia kobiet

${ }^{1}$ M. Kuryłowicz, A. Wiliński, Rzymskie prawo prywatne, Zakamycze, Kraków 1999. 
dotyczyły wywalczenia praw wyborczych, prawa do nieograniczonego dysponowania własnym majątkiem, dostępu do nauki i pracy w zawodach dotychczas zarezerwowanych dla mężczyzn, to do ich pierwszych sukcesów już w połowie XIX w. należy zaliczyć dopuszczenie kobiet do studiowania i do oficjalnej pracy naukowej². Współczesne ujęcie emancypacji akcentuje uwolnienie się od zależności i zdobycie lepszej pozycji w strukturze społecznej3, a analiza synonimów słowa "emancypacja” czyni ten termin jeszcze przyjaźniejszym dla określenia dążeń i praw osób z niepełnosprawnością. Są tam takie słowa jak: ocalenie, odbicie, oswobodzenie, ratunek, równouprawnienie, uniezależnienie, usamodzielnienie, uwolnienie, wybawienie, wyswobodzenie, a każde $\mathrm{z}$ nich analizowane $\mathrm{w}$ odniesieniu do konkretnej sytuacji i konkretnego człowieka przynosi jedynie pozytywne skojarzenia z przyznaniem pełni praw do realizacji siebie osobom z niepełnosprawnością. Jedna tylko refleksja nie daje spokoju: jeśli jest tyle praw, które gwarantuje emancypacja, to gdzie jest odpowiedzialność za tyle swobody? Czy otrzymanie wolności i praw nie zobowiązuje jednocześnie do brania odpowiedzialności za własne decyzje? O ile przeciętny człowiek wychowujący się $\mathrm{w}$ danym społeczeństwie, realizujący zgodnie $\mathrm{z}$ wiekiem swoje zadania życiowe, przyjmujący sukcesywnie różne role społeczne uczy się tej odpowiedzialności nieomal automatycznie, to gdzie, kiedy i jak ma się nauczyć tej odpowiedzialności (również za własne życie i decyzje związane z osobistymi wyborami!) człowiek z niepełnosprawnością, kiedy niejednokrotnie osiąga sprawność w zakresie różnych funkcji później niż jego rówieśnicy, a więc i proces jego socjalizacji nie przebiega w sposób naturalny i sukcesywny? O ile dzieci i młodzież sprawna intelektualnie, ale niesprawna sensorycznie lub ruchowo jest zdolna do opanowania większości powinności ciążących na każdym członku społeczeństwa, o tyle osoby z niepełnosprawnością intelektualną, zwłaszcza

2 The Routledge Companion to Feminism and Postfeminism, red. S. Gamble, Routlage, London - New York 1999.

3 Słownik języka polskiego PWN, www.spj.pwn.pl [30.11.2015]. 
w stopniu umiarkowanym i głębszym, nie tylko nie są w stanie pełnić niektórych funkcji społecznych, ale także nie zawsze są zdolne do podejmowania niezależnych decyzji w wielu aspektach życia, łącznie z decyzjami dotyczącymi ich samych. Jak w tej sytuacji mówić o niezależności, wyzwoleniu i o emancypacji wreszcie? Emancypacja odnosi się do osób biorących aktywny udział w procesie uniezależnienia się, natomiast integracja i inkluzja ma na względzie istnienie i godne człowieka funkcjonowanie w społeczeństwie, które uprzednio musi być przygotowane na taką koegzystencję ${ }^{4}$. Chociaż wszystkie te zjawiska wymagają także od człowieka z niepełnosprawnością gotowości i odpowiedniego poziomu przystosowania do warunków, w których żyje większość jego społeczności, to jednocześnie na społeczeństwo nakłada się obowiązek respektowania specjalnych warunków i możliwości korzystania z pełni człowieczych praw ludzi, którzy mają gorsze anatomiczno-fizjologiczne warunki adaptacji do świata. W tym kontekście, gdy mówimy o integracji i inkluzji, akcentujemy głównie zewnętrzne w stosunku do osoby niepełnosprawnej warunki, które muszą być spełnione, aby niepełnosprawność nie była czynnikiem dyskryminującym ${ }^{5}$. Kiedy natomiast zaczynamy mówić o emancypacji - zgodnie z etiologią tego słowa - oczekujemy, że ciężar działań na własną rzecz będzie leżał na barkach samych osób z niepełnosprawnością i że to one będą wykazywały największą aktywność w kwestii własnej emancypacji. Teoretycznie kierunek takiego rozumowania jest właściwy, ale uzyskanie takiego poziomu autonomii wobec własnej osoby oraz takiego poziomu świadomości wobec własnych kompetencji, praw i - nie zapominajmy - wobec obowiązków oraz odpowiedzialności, wymaga odpowiedniego poziomu dojrzałości intelektualnej i osobowościowej. I tu - jak bumerang - wraca sprawa osób ze znacznie obniżoną sprawnością intelektualną. Czy one tak-

${ }^{4}$ G. Szumski, Integracyjne ksztatcenie niepetnosprawnych, APS, Warszawa 2006.

${ }^{5}$ Reflection of Inclusive Education of the 21st Century in Correlative Scientific Field, red. V. Lechta, B. Kudláčová, Peter Lang International Academic Publishers, Frankfurt am Main 2013. 
że są zdolne do emancypacji? A może wobec nich zastosować pojęcie ograniczonej emancypacji - tylko czy to nadal będzie emancypacja i czy o to chodzi w procesie rehabilitacji?

\section{Warunki emancypacji}

Chociaż klasyczne pojęcie emancypacji zakłada, że inicjatywa zmiany swojego położenia wychodzi od osoby bezpośrednio zainteresowanej, to jednocześnie zakłada się, że osoba ta jest w pełni świadoma, co chce osiągnąć nie tylko dla siebie, ale i dla określonej grupy ludzi, z którymi zazwyczaj się identyfikuje. Musi to więc być osoba dorosła, już pod niektórymi względami na tyle niezależna, że może sama decydować o własnym losie. To samo zapewne dotyczy osób z niepełnosprawnością, do których zamierzamy odnieść pojęcie emancypacji. Nie można bowiem uznać, że usilne i konsekwentne domaganie się przez dziecko (także pełnosprawne) jakiejś zabawki, towarzystwa rodzica czy nawet czułości jest aktem emancypacji. To też oczywiście jest domaganie się swoich praw i ich realizacja może zmienić pozycję dziecka wśród rówieśników czy rodzeństwa, ale nie ma to nic wspólnego z emancypacją. Do emancypacji trzeba dojrzeć pod względem intelektualnym, emocjonalnym i społecznym, a żadne dziecko takich kryteriów jeszcze nie spełnia. Wobec tego pojęcie emancypacji wraz z wszelkimi działaniami emancypacyjnymi musimy zarezerwować dla osób dorosłych lub prawie dorosłych, np. dla młodzieży, która jest świadoma własnych dążeń, sposobów ich realizacji i na ogół - konsekwencji uzyskania żądanych praw.

O tym, że prawa osób z niepełnosprawnością na świecie, w krajach Unii Europejskiej i w poszczególnych lokalnych zwyczajach nie są w pełni respektowane, nie trzeba dziś już nikogo przekonywać. To są bariery wdrożenia $w$ życie istniejących już i dobrych regulacji prawnych, co implikuje ciągłą konieczność działań prointegracyjnych i proinkluzyjnych. Największy opór w ich właściwym wdra- 
żaniu leży po stronie pierwiastka ludzkiego 6 i to jest nadal zadanie szeroko pojętego procesu rehabilitacji, obejmującego środowisko społeczne osób z niepełnosprawnością. Co się jednak tyczy emancypacji, może ona być traktowana jako jeszcze jeden, nowy i bardzo potrzebny nurt rehabilitacji skierowany bezpośrednio na osoby $\mathrm{z}$ niepełnosprawnością $\mathrm{i}$ to nie $\mathrm{w}$ chwili, gdy osiągną dostateczny poziom dojrzałości psychospołecznej, która pozwoli im na włączenie się w działania emancypacyjne, ale od samego początku ich rozwoju jako osoby niepełnosprawnej. Nieco inaczej będzie to wyglądało wobec dzieci urodzonych z niepełnosprawnością, a inaczej wobec osób, których niepełnosprawność zaistniała w późniejszym wieku i to zależnie od sposobu i czasu zaistnienia niepełnosprawności. Tu największy udział w procesie rehabilitacji będą mieli psychologowie, ale oni również powinni uczestniczyć we wczesnej wieloaspektowej, interdyscyplinarnej rehabilitacji małego dziecka, aby doprowadzić do ukształtowania takich predyspozycji osobowościowych, które w przyszłości pozwolą skutecznie zmagać się z niepełnosprawnością, czyniąc jednostkę zdolną do autorehabilitacji ${ }^{7}$. Jednak zadania rehabilitacyjne przypadające na ten czas rozwoju, który trwa aż do początku adolescencji, są rozdzielone pomiędzy dorosłych sprawujących pieczę nad dzieckiem, a psycholog odgrywa rolę koordynatora i terapeuty rodziców dziecka $\mathrm{z}$ niepełnosprawnością, a czasem także innych członków rodziny. To do niego należy dbałość o właściwą atmosferę wychowawczą w rodzinie dziecka z niepełnosprawnością, do niego należy pomoc w sytuacjach kryzysu emocjonalnego rodziców po otrzymaniu informacji o niepełnosprawności dziecka, do niego należy dbałość o postawę akceptującą dziecko takim jakie jest, a więc razem z jego ogranicze-

${ }^{6}$ S. Przybylski, Refleksje nad barierami wystęującymi przy wdrażaniu integracji osób niepetnosprawnych w Polsce na początku nowego tysiąclecia, [w:] Integracja osób niepetnosprawnych w edukacji i interakcjach społecznych, red. Z. Kazanowski, D. Osik-Chudowolska. Wydawnictwo UMCS, Lublin 2003, s. 23.

${ }^{7}$ J. Konarska, Zdolność do autorehabilitacji jako konsekwencja wcześniejszych zabiegów wychowawczo-rehabilitacyjnych, "Annales" 2014a, vol. XXVII, Nr 1, sectio J. UMS, Lublin, s. 35-56. 
niami, ale szczególnie z jego potencjałem rozwojowym, którego wzrastanie może nastąpić jedynie wskutek impulsów umiejętnie dawkowanych przez najbliższych. Do psychologa wreszcie należy zadbanie także o pełnosprawne dzieci w rodzinie, które nader często nieświadomie są traktowane przez dorosłych instrumentalnie w stosunku do potrzeb dziecka niepełnosprawnego, a to rzutuje negatywnie na przyszłe relacje emocjonalne i partnerskie między dorosłymi już dziećmi. Jeśli potrzeby dziecka niepełnosprawnego są zaspokajane kosztem potrzeb innych dzieci w rodzinie, to istnieje ryzyko ukształtowania postawy roszczeniowej wobec innych członków społeczeństwa w przyszłości, a to już zupełnie wyklucza rozumienie przez takich dorosłych $\mathrm{z}$ niepełnosprawnością istoty emancypacji.

\section{Dyskursy o emancypacji w pedagogice}

Inicjatorem pedagogiki emancypacyjnej nie był pedagog, ale prawnik - Paulo Freire, który był związany z edukacją poprzez propagowanie w latach 50. i 60. idei "kształcenia uciśnionych" w Brazylii poprzez alfabetyzację dorosłych i zapobieganie w ten sposób wykluczeniu i marginalizacji niewykształconych, ubogich Brazylijczyków ${ }^{8}$. Pomiędzy wychowaniem i emancypacją istnieją związki, na które wskazuje Maria Czerepaniak-Walczak ${ }^{9}$. W odniesieniu do osób z niepełnosprawnością i ich kształcenia istotne wydają się dwa z nich: wychowanie do emancypacji i emancypacja przez wychowanie. Pierwszy - akcentuje stwarzanie warunków sprzyjających osiąganiu autonomii poprzez kształtowanie cech osobowości i tu wskazuje Czerepaniak-Walczak na otwartość, odwagę, godność i mobilność. Otwartość odwaga i godność to na pewno cechy osobowości, które powinien posiadać każdy człowiek dążący

${ }^{8}$ H. Kostyłlo, Przestanie „pedagogiki uciśnionych” Paula Freire, „Forum Oświatowe" 2011, nr 2(45).

${ }_{9}^{9}$ M. Czrepaniak-Walczak, Pedagogika emancypacyjna, GWP, Gdańsk 2006. 
do niezależności i samorealizacji. Z mobilnością rozumianą dosłownie osoby $\mathrm{z}$ niepełnosprawnością mogą mieć problem, ale jeśli przez mobilność rozumieć zdolności adaptacyjne do zmieniającej się rzeczywistości, to - poza osobami z upośledzeniem umysłowym - mobilność jest osiągalna.

Emancypacja przez wychowanie jest raczej postulatem odnoszącym się do pedagogów, bo jest tu mowa o tym, że powinna ona być celem wychowania i wyznacznikiem jego treści oraz form.

Amadeusz Krause dokonuje analizy postulatów pedagogiki emancypacyjnej do humanistycznej orientacji $\mathrm{w}$ pedagogice specjalnej, wyodrębniając w niej paradygmat emancypacyjny i jakościowy ${ }^{10}$. Na realizację paradygmatu emancypacyjnego (teoretycznie obecnego w okresie socjalizmu) pozwoliły zmiany ideologicznopolityczne w Polsce, które nastąpiły po 1989 r. Osoby z niepełnosprawnością są traktowane $\mathrm{w}$ wielu obszarach życia - także $\mathrm{w}$ edukacji - podmiotowo, a poprzez edukację zmierza się do uzyskania przez osoby z niepełnosprawnością nie tylko autonomii, ale także pewnego rodzaju wyzwolenia spod jarzma roli przypisywanej im przez ludzi pełnosprawnych. Krause odnosi się także do możliwości osiągania celów emancypacyjnych przez osoby $\mathrm{z}$ niepełnosprawnością intelektualną, słusznie zauważając, że w przypadku głębszej niepełnosprawności osoby te nie mają możliwości samostanowienia, ale zwraca uwagę na rolę self-adwokatów, którzy działają $\mathrm{w}$ imieniu podopiecznych. Jednak nie wydaje się to być idealnym rozwiązaniem, zwłaszcza, że liczni autorzy: Andrzej Twardowski1 ${ }^{11}$, Beata Tylewska-Nowak ${ }^{12}$, Kennedy i Wonnacot ${ }^{13}$

10 A. Krause, Wspótczesne paradygmaty pedagogiki specjalnej, Impuls, Kraków 2010.

${ }^{11}$ A Twardowski, Oddziaływania rodziców blokujące rozwój autonomii u dzieci upośledzonych umysłowo, [w:] Społeczeństwo wobec autonomii osób niepetnosprawnych, red. W. Dykcik, Eruditus Poznań 1996, s. 145-154.

12 B. Tylewska-Nowak, Autonomia osób z głębsza niepetnosprawnościa intelektualna w opinii wybranych grup społecznych, UAM, Poznań 2001.

${ }^{13}$ M. Kennedy, J. Wonnacot, Neglect of disabled children,' [w:] Child neglect. Practice issues for health and social care, red. J. Taylor, B. Daniel, Jessica Kingsley Publishers, London - Philadelphia 2005, s. 228-248. 
wskazują na działania opiekunów i środowiska blokujące rozwój autonomii. Zresztą nie tylko o autonomię tu chodzi, ale także o jej zakres, co jednak przywołuje refleksje o odpowiedzialności samych osób z niepełnosprawnością i opiekunów.

W kontekście emancypacji Głuchych Dorota Podgórska-Jachnik ${ }^{14}$ podejmuje dyskusję o zasadności mówienia o emancypacji osób z niepełnosprawnością. Nawiązuje do opinii

Bogusława Śliwerskiego ${ }^{15}$ i Amadeusza Krause ${ }^{16}$, podkreślając akcentowanie przez obu autorów wątku autonomii, podmiotowości i wolności w pedagogice emancypacyjnej. Porównuje ze sobą określenie „być samodzielnym” i "być autonomicznym”, przyznając temu drugiemu szerszy zakres pojęciowy, mający także odniesienie do praktyki rehabilitacyjnej, w zakres której wchodzi nie tylko usamodzielnienie w czynnościach życiowych, lecz także autonomia i niezależność w różnych obszarach życia psychicznego łącznie z samostanowieniem. Początków pedagogiki emancypacyjnej wobec osób z niepełnosprawnością doszukuje się D. Podgórska-Jachnik w końcu XX w. w postawach Aleksandra Hulka17, Ottona Lipkowskiego ${ }^{18}$, Janiny Doroszewskiej19, Zofii Sękowskiej20 wobec kształcenia i rehabilitacji osób z niepełnosprawnością.

Istnieje pewne niebezpieczeństwo nazywania pedagogiką emancypacyjną wszystkich postępowych nurtów w pedagogice, na co zwraca uwagę A. Krause ${ }^{21}$, przytaczając jednocześnie słowa Lecha Witkowskiego 22: „wygodna etykieta »pedagogiki emancypacyjnej«

14 D. Podgórska-Jachnik, Gtusi. Emancypacje, WSP, Łódź 2013.

15 B. Śliwerski, Wspótczesne nurty i teorie wychowania, Impuls, Kraków 2001

16 A. Krause, op. cit.

17 Pedagogika rewalidacyjna, red. A. Hulek, PWN, Warszawa 1980.

18 O. Lipkowski, Pedagogika specjalna. Zarys, PWN, Warszawa 1979.

19 J. Doroszewska, Pedagogika specjalna, Ossolineum, Wrocław 1989.

20 Z. Sękowska, Pedagogika specjalna, Wydawnictwo UMCS, Lublin 1978.

${ }^{21}$ A. Krause, Teoretyczne inspiracje pedagogiki specjalnej - pedagogika emancypacyjna, "Studia Edukacyjne“ 2013, nr 28, s. 10.

${ }^{22}$ L. Witkowski, O stanie i problemach recepcji pedagogiki radyklanej w Polsce, [w:] Edukacja i sfera publiczna, idee i doświadczenia pedagogiki radykalne, red. H.A. Giroux, L. Witkowski, Impuls, Kraków 2010, s. 58. 
gubi $\mathrm{w}$ istocie poważne $\mathrm{i}$ trudne pytanie o potencjał emancypacji w każdej pedagogice”. A. Krause konkluduje: „W tym stwierdzeniu Lecha Witkowskiego dochodzimy do (...) problemu zasadności wyodrębniania tej pedagogiki w ogóle".

\section{Kształtowanie osobowości zdolnej do emancypacji}

Od momentu podjęcia nauki szkolnej pedagog kształtuje poczucie własnej wartości dziecka $\mathrm{w}$ oparciu o jego postępy szkolne i stymuluje jego umiejętność współżycia w grupie społecznej. Zatem osobowość... Czy osoba z niepełnosprawnością musi mieć określone cechy osobowości, aby dążyć do emancypacji? W teoriach osobowości uwzględnia się nie tylko cechy, które wynikają z konstruktywnych właściwości centralnego układu nerwowego, ale także te, które mogą być ukształtowane przez środowisko w sposób celowy lub przypadkowy i na które warunki życia, a zwłaszcza doświadczenie osobiste, mają niebagatelny wpływ. Bardzo szczegółowego opisu i pomiaru takich cech osobowości dokonał Raymond Bernard Cattell23 i dlatego, posługując się jego teorią, można wymienić niektóre cechy osobowości, które ułatwiają wyznaczanie i osiąganie stawianych sobie celów, a działania emancypacyjne na tym m.in. polegają.

Niewątpliwie cechą ułatwiającą podejmowanie wszelkich wyzwań życiowych na różnym etapie rozwojowym jest odpowiednia do wieku dojrzałość emocjonalna (u Cattella oznaczona symbolem C), która ma ścisły związek z umiejętnością oceniania własnych kompetencji $w$ danym zakresie i poczuciem pewności siebie (czynnik $\mathrm{O}$ ), a oba te czynniki mają związek z odpornością na frustrację (czynnik $\mathrm{Q}_{4}$ ). Wymienione cechy osobowości nie są jedynymi wskaźnikami udanego, satysfakcjonującego życia, ponieważ każda jednostka

${ }^{23}$ H.E.P. Cattell, A.D. Mead, The Sixteen Personality Factor Questionnaire (16PF), [w:] The SAGE Handbook of Personality Theory and Assessment: Vol. 2 - Personality Measurement and Testing, red. G.J. Boyle et al., Sage, Los Angeles 2008, s. 135-159. 
żyje w określonych warunkach społecznych, w których może bardziej lub mniej realizować swoje plany życiowe, a to już nie zawsze zależy jedynie od jej własnych predyspozycji. Niemniej jednak warto sięgnąć do badań ukazujących związek cech osobowości z satysfakcją życiową, której jednym ze wskaźników jest możliwy do obiektywnego pomiaru psychologicznego poziom poczucia sensu życia ${ }^{24}$.

Emancypacja w tym kontekście może być wyrazem świadomego dążenia nie tylko do podniesienia jakości własnego życia, ale także elementem realizacji sensu własnego życia. Może to być szerzej pojęte zadanie życiowe, które ma na względzie swoje osobiste cele emancypacyjne, a w dalszej perspektywie, poprzez utożsamianie się z grupą osób o tej samej niepełnosprawności czy niepełnosprawności w ogóle, występowanie jako rzecznik praw innych ludzi z niepełnosprawnością. Nie oznacza to oczywiście, że każdy człowiek z niepełnosprawnością, który osiągnął wysoki stopień emancypacji będzie także występował $\mathrm{w}$ imieniu innych jednostek. To, czy zechce, zależy od jego indywidualnych potrzeb, od jego skłonności osobowościowych, często od sytuacji i pozycji społecznej czy zawodowej, ale nie oznacza to równocześnie, że powinniśmy oczekiwać od każdej wyemancypowanej osoby z niepełnosprawnością również działań na szerszą skalę społeczną. Wypracowanie własnej niezależności i zgodnego z umiejętnościami oraz wykształceniem miejsca w społeczeństwie, umiejętność zaspokajania potrzeb w sposób akceptowany społecznie i satysfakcjonujący osobiście jest już wystarczającym "wyczynem” zasługującym na traktowanie danej osoby po partnersku, a nie od każdego, kto ma powodzenie w życiu oczekujemy przecież filantropii.

Co wobec tego należy do zadań specjalistów: pedagogów, psychologów i innych oraz do samych rodziców, aby takie cechy osobowości ukształtować u dziecka z wcześnie nabytą niepełnosprawnością czy urodzonego jako niepełnosprawne?

24 Por. K. Popielski, Noetyczny wymiar osobowości. Psychologiczna analiza poczucia sensu życia, RW KUL, Lublin 1993; por. J. Konarska J., Psychospołeczne korelaty poczucia sensu życia a niepetnosprawność, GWSP, Mysłowice 2002, s. 89-108. 
Wobec niezliczonej ilości podręczników pedagogicznych, znalezienie odpowiedzi na to pytanie nie wydaje się trudne, ale $\mathrm{z}$ pewnością należy zwrócić uwagę na większy udział psychologów w procesie wczesnego wspomagania rozwoju dziecka. Stała tendencja do mnożenia ośrodków wczesnego wspomagania rozwoju i intensyfikowania działań skierowanych na dziecko, coraz większe doświadczenie i kompetencje praktyków pracujących bezpośrednio z dzieckiem są bardzo dobrym przejawem troski o wszechstronny rozwój dzieci z niepełnosprawnością. Jednak są to przede wszystkim działania skierowane na mechaniczne wyćwiczenie pewnych funkcji niezbędnych do osiągnięcia niezależności $w$ samoobsłudze, niezbędnych do podjęcia nauki szkolnej, a zbyt mało uwagi poświęca się wypracowaniu cech stanowiących trzon przyszłej osobowości. Chodzi tu między innymi o cierpliwość i wytrwałość, ale nie tylko okupioną wysiłkiem fizycznym i nierzadko bólem, ale o wzbudzenie odpowiedniej motywacji i wplatanie - zwłaszcza trudnych zadań rehabilitacyjnych - w czynności zabawowe, w których planowaniu ma udział również samo dziecko. Trzeba także pamiętać, że założone przez rehabilitanta cele nie mogą być odleglejsze niż te, które swoim umysłem jest zdolne ogarnąć dziecko, a to wiąże się ze znajomością ogólnorozwojowych praw. Dozowanie satysfakcji $\mathrm{z}$ osiągniętego celu lub tylko z małego postępu, nagradzanie dziecka za najmniejszy „krok naprzód”, to czynności nie mniej ważne niż sama technika konkretnej terapii. Wreszcie nie można sprowadzać roli rodziców do tych, którzy są jedynie odpowiedzialni za wykonywanie poleceń terapeutów i pilnowanie regularności zadanych ćwiczeń, bo są to partnerzy, którzy także powinni być świadomi celów rehabilitantów, ale i możliwości oraz ograniczeń dziecka. Tylko wówczas będą kompetentnie wspomagać proces rehabilitacji, staną się inicjatorami własnych pomysłów na zachęcenie podopiecznego do wspólnej zabawo-terapii. Rodzic aktywnie i świadomie uczestniczący $w$ rehabilitacji własnego dziecka dostaje jednocześnie skuteczną broń $\mathrm{w}$ walce $\mathrm{z}$ własną bezradnością wobec niepełnosprawności dziecka i jest to skuteczny sposób zapobiegania 
patologicznym zmianom kryzysowym u rodziców. Ten aspekt procesu rehabilitacyjnego nie jest na ogół uwzględniany w ośrodkach terapeutycznych, a zajęcia wspierające rodziców są raczej fikcją ${ }^{25}$.

\section{Emancypacja a samorealizacja}

Czy kiedy mówimy o osobach z niepełnosprawnością, istnieje jakieś powiązanie między pojęciami „emancypacja” i „samorealizacja”?

Samorealizacja nigdy nie dokonuje się $\mathrm{w}$ samotności, chociaż jest to indywidualny wysiłek $\mathrm{i}$ indywidualna droga rozwoju każdej jednostki ludzkiej. Zakładamy, że jest to kierunek rozwoju osobistego każdego człowieka, ale jednocześnie psychologia dopuszcza fakt, że nie każdy człowiek osiąga taki poziom rozwoju osobowości, aby być zdolnym do samorealizacji. W dodatku - nawet jeśli jednostka osiągnie pewien wcześniej założony poziom samorealizacji to już sama zdolność do samorealizacji powoduje wyznaczanie sobie jeszcze ambitniejszego celu rozwojowego, a proces ten wówczas nigdy się nie kończy. $W$ ten sposób podjęty trud samodoskonalenia daje na każdym etapie realizacji doznanie satysfakcji osobistej i, nie powodując frustracji, wznosi człowieka na jeszcze wyższe szczeble drabiny rozwojowej, ucząc odporności na niepowodzenia (cattellowski czynnik $\mathrm{Q}_{4}$ ), dając poczucie pewności siebie i umiejętność kontrolowania własnych stanów emocjonalnych (czynnik $\mathrm{O}$ i C), ale także pomagając nawiązywać i utrzymywać satysfakcjonujące relacje interpersonalne (cattellowski czynnik A). To wszystko przekłada się także na racjonalizm, trzeźwy stosunek do życia i samego siebie (czynnik N) oraz sprzyja wysokiej samoocenie (czynnik $Q_{3}$ ). Każda osoba posiadająca te cechy osobowości ma predyspozycje psychiczne, aby być niezależną, dobrze zorganizowaną i świadomą swoich

${ }^{25}$ J. Konarska, Wsparcie rodziców w ramach wczesnej interwencji na terenie Polski raport z badań, [w:] Profilaktyka $i$ terapia z perspektywy współczesnej pedagogiki, red. J. Szempruch, Z. Zbróg, A. Ratajek, Wydawnictwo Uniwersytetu Humanistyczno-Przyrodniczego, Kielce 2011, s. 179-190. 
celów jednostką. To wystarcza, aby w razie potrzeby realizować plany emancypacyjne wobec siebie, lub/i innych osób. Jeśli z psychologicznego punktu widzenia można ustalić cechy osobowości niezbędne do samorealizacji, a emancypację można uznać za jeden ze sposobów wyrażania samorealizacji, to pozostaje tylko - a może aż - problem odpowiedniej organizacji, zaplanowania i przebiegu procesu rehabilitacyjnego, w którym dążność do realizacji wyraźnie określonych zadań emancypacyjnych będzie uwzględniona.

$\mathrm{Na}$ pewno $\mathrm{w}$ ten długotrwały proces musi być zaangażowany cały zespół specjalistów, łącznie z rodzicami, którzy - odpowiednio prowadzeni - z czasem także stają się ekspertami w procesie rehabilitacji własnego dziecka. Ponieważ rehabilitacja nie jest działaniem anonimowym, ale zawsze skierowana jest na konkretnego człowieka, dlatego pełna świadomość jego aktualnych ograniczeń, potencjalnych możliwości, wiekowych właściwości rozwojowych, jednostkowej sytuacji rodzinnej i szerzej pojętych warunków środowiskowych musi być podstawą tworzenia długodystansowego planu rehabilitacyjnego, który wyznaczają konkretne zadania rozwojowe. $W$ ten sposób planowane działania rehabilitacyjne można podzielić na poszczególnych członków zespołu rehabilitacyjnego, łącznie z zadaniami, które dotyczą samej osoby z niepełnosprawnością, uwzględniając jej wiek ${ }^{26}$.

Małemu dziecku, które jeszcze nie rozumie własnej odrębności, ponieważ nie ma jeszcze poczucia tożsamości własnej, nie można przydzielać żadnych zadań, ale jego rodzicom - tak. Niestety w obecnej praktyce terapeutycznej nie bierze się absolutnie pod uwagę stanu psychicznego rodziców dziecka, którzy dobrowolnie zgłaszają się z nim do ośrodka wczesnego wspomagania rozwoju, uznając, że skoro sami szukają pomocy dla swojego dziecka, to znaczy, że są w dobrym stanie psychicznym i dostatecznie silni, aby

${ }^{26} \mathrm{~J}$. Konarska, Zadania rozwojowe $i$ życiowe dzieci $i$ młodzieży niepetnosprawnej w kontekście dynamizowania osobistych oraz środowiskowych zasobów, [w:] Dzieci i młodzież ze specjalnymi potrzebami edukacyjnymi w realizacji zadań rozwojowych, red. B. Witkowska, K. Bidziński, P. Kurtek, Wydawnictwo Uniwersytetu Humanistyczno-Przyrodniczego, Kielce 2010, s. 324-330. 
obarczać ich zadaniami dla nich przeznaczonymi i odpowiedzialnością za postępy w rozwoju dziecka. Tym samym zostaje zignorowany obowiązek udzielenia pomocy rodzinie, które to zadanie mają terapeuci wpisane $\mathrm{w}$ program rehabilitacji małego dziecka i które stanowi drugi człon nazwy ośrodków wczesnego wspomagania rozwoju dziecka. Przeżycia rodziców i ich stan emocjonalny był poddawany wielokrotnie dyskusji specjalistów ${ }^{27}$, ale to ciągle za mało, aby zmienić istniejącą rzeczywistość w praktyce. Prawdopodobnie przyczyną takiego stanu rzeczy jest brak psychologów-rehabilitantów, dla których problemy samej osoby z niepełnosprawnością w każdym wieku oraz jej szeroko pojętego środowiska są obce, a zatrudnieni w ośrodkach wczesnego wspomaganie rozwoju psychologowie koncentrują się przede wszystkim na postawieniu diagnozy wobec małego pacjenta i monitorowaniu jego postępów w miarę rehabilitacji, natomiast rodzicom nie potrafią skutecznie pomóc, a jeśli to robią, to w oparciu bardziej o intuicję i własne doświadczenie niż o konkretną wiedzę, do której ośrodki akademickie ich nie przygotowują. Zresztą sami rodzice także z braku czasu i obciążenia nadmiarem obowiązków niespecjalnie zabiegają o taką pomoc ${ }^{28}$.

Tymczasem efekty działań rodzicielskich wobec dziecka zależą w dużej mierze nie tylko od ich stanu psychicznego, ale także od poziomu świadomości zadań jakie stoją przed nimi nie tylko wobec małego dziecka, ale aż do chwili, kiedy osiągnie ono maksymalny poziom sprawności funkcjonalnej. Nawet wówczas, kiedy wydaje się, że dorastające bądź dorosłe dziecko $\mathrm{z}$ niepełnosprawnością osiągnęło wystarczający do bycia niezależnym człowiekiem poziom rozwoju i sprawności, rodzicom grozi kolejny kryzys emocjonalny

27 A. Twardowski, Sytuacja rodzin dzieci niepetnosprawnych, [w:] Dziecko niepetnosprawne w rodzinie, red. I. Obuchowska, WSiP Warszawa 1991, s. 18-53; J. Konarska, Niepetnosprawność dziecka jako sytuacja kryzysowa w rodzinie, [w:] Kryzys, interwencja i pomoc psychologiczna. Nowe ujęcia i możliwości, red. D. Kubacka-Jasiecka, K. Mudyń, Wydawnictwo A. Marszałek, Torun 2003, s. 28-43.

${ }^{28} \mathrm{~J}$. Konarska, Wsparcie rodziców w ramach wczesnej interwencji na terenie Polski raport z badań, [w:] Profilaktyka i terapia..., s. 179-190. 
i znowu potrzebna im pomoc psychologiczna, bo inaczej nie pozwalają swojemu dziecku na korzystanie z efektów rehabilitacji ${ }^{29}$.

Podstawowym zadaniem rodziców jest bycie nieustannym rehabilitantem swojego dziecka, rehabilitantem, którego nikt nie zastąpi i który nie ma prawa wypalić się. To na ich barkach spoczywa obowiązek całodobowego wychowania, które nieustannie przeplatane jest $\mathrm{z}$ działaniami rehabilitującymi. $\mathrm{W}$ ostatnich latach często podejmowany wątek wypalenia zawodowego osób zajmujących się ludźmi z niepełnosprawnością pozwolił na zwrócenie uwagi na ważny problem społeczny i przeniósł się także na grunt rodzicielski30. Jednak w odróżnieniu od wszystkich specjalistów nie radzących sobie $z$ ogromnym przeciążeniem i napięciem psychicznym ze względu na stały kontakt i odpowiedzialność za osoby z niepełnosprawnością, rodzice nie mają żadnej alternatywy wobec zmiany w swoim życiu, bo ich przecież nikt nie jest w stanie zastąpić i dlatego nie można ignorować konieczności udzielania im profesjonalnej pomocy psychologicznej w każdym momencie ich załamania psychicznego. O ile terapeutę można zmienić i o ile terapeuta może zmienić obszar swojej aktywności zawodowej, o tyle rodzicom taki luksus wyboru nie przysługuje!

Rodzice muszą się przede wszystkim nauczyć być rodzicem dziecka - tego konkretnego dziecka - i nietypowej dla siebie roli zarówno rodzica, jak i rehabilitanta. A bycie rehabilitantem wymaga wiedzy i taką wiedzę - a nie jedynie instrukcje ćwiczeń rehabilitacyjnych - powinien przekazać mu zespól terapeutów pracujący z dzieckiem. Wiedza ta nie może ograniczać się do wyjaśnienia istoty niepełnosprawności, ale musi zawierać elementy motywujące rodzica do podejmowania codziennego wysiłku rehabilitacyjnego i musi dawać rodzicom nadzieję na poprawę sytuacji dziecka w najbliższej przyszłości oraz w dalszej perspektywie. Ta nadzieja

${ }^{29}$ J. Konarska, Kryzysy młodzieży z niepetnosprawnością versus kryzysy rodziców, [w:] Kryzysy i ich przezwyciężanie. Problemy interwencji i pomocy psychologicznej, red. D. Kubacka-Jasiecka, K. Mudyń, Wydawnictwo A. Marszałek, Toruń 2014, s. 119-140.

${ }^{30}$ M. Sekułowicz, Wypalanie się sit rodziców dzieci z niepetnosprawnością, DSW, Wrocław 2013. 
oparta o poczucie sprawczości własnej daje siły do pracy z dzieckiem, zapobiega bezsilności i w dużej mierze zabezpiecza przed wypalaniem się.

Nie można zapominać o aktywnej roli samego dziecka, które rośnie, dojrzewa psychicznie i powoli - podobnie jak jego rówieśnicy, chociaż czasami z opóźnieniem - podejmuje odpowiedzialność za swoje życie, jego kształt, stawia sobie cele życiowe, przekształca je w dążenia samorealizacyjne i nadaje im swoistą wartość, czyniąc z nich sens własnego życia.

\section{Zakończenie}

Jeśli aktywność własna ukierunkowana na samodzielne dążenie do samorealizacji jest jednym z założeń emancypacji, to można przyjąć, że osiągnięcie takich umiejętności jest jednocześnie uwieńczeniem długotrwałego procesu rehabilitacji. Początkiem drogi do emancypacji jest ukierunkowanie małego dziecka na samodzielność, zaradność i umiejętność samodzielnego wykorzystywania potencjału własnego ciała, umysłu i wszystkich tych możliwości rozwojowych, których nie przesłania niepełnosprawność. Takie ukierunkowanie wymaga traktowania dziecka w sposób podmiotowy i jednocześnie mocno zindywidualizowany, a ponieważ jest to zadanie rodziców, to $\mathrm{w}$ ich działaniach można doszukiwać się zasad pedagogiki emancypacyjnej. Dalszy ciąg emancypacji dokonuje się przy udziale rehabilitantów, pedagogów w szkole i - co najważniejsze - zaczyna być udziałem samej osoby z niepełnosprawnością, przyjmując formę autorehabilitacji. W tych procesach nie wolno człowiekowi przeszkadzać, bo jeśli one zaistniały, to są przejawem sukcesu rehabilitacyjnego. Niestety często się zdarza, że plany życiowe dorastającej młodzieży z niepełnosprawnością czasem przerażają - zwłaszcza rodziców - swoją odwagą i rozmiarami i wówczas zaczynają traktować swoje prawie dorosłe dziecko przedmiotowo, chroniąc przed wyimaginowanym niebezpieczeństwem. Wracamy w tym momencie do obaw pedagogów specjalnych związanych z tenden- 
cją do nadopiekuńczości rodziców i hamowania rozwoju autonomii. Michael Wehmeyer i Nancy Garner ${ }^{31}$ twierdzą, że to, jaki stopień autonomii osiągnie osoba z niepełnosprawnością, zależy w głównej mierze od czynników środowiskowych, a nie od jej zdolności intelektualnych.

Nawiązując do pedagogiki emancypacyjnej M. Czerepaniak-Walczak ${ }^{32}$, sposób traktowania osoby z niepełnosprawnością przez rodziców także jest wychowaniem do emancypacji.

Emancypacja w kontekście zachowań samorealizacyjnych nie jest koncepcją nową, bo wkomponowuje się w istniejący już wachlarz terminów określających cele rehabilitacyjne i konkretne rezultaty rehabilitacji, które łatwiej zauważyć w odniesieniu do konkretnego człowieka/konkretnych ludzi, niż przypisać te dokonania całej grupie osób z niepełnosprawnością o zróżnicowanym poziomie ich dysfunkcji biopsychicznych. Zazwyczaj lepsze efekty rehabilitacyjne odnosi się tam, gdzie nie ma pułapu rozwojowego wyznaczonego przez organiczne bariery, a o tych możemy mówić jedynie w sytuacji upośledzenia umysłowego. Wszelki inny rodzaj niepełnosprawności przy współczesnych osiągnięciach technicznomedycznych nie określa granicy możliwości ludzkich, dając tym samym nieograniczone pole do popisu zarówno rehabilitantom, jak i samej jednostce dotkniętej niepełnosprawnością. Wydaje się, że najbardziej dotkliwym ograniczeniem są obecnie bariery ekonomiczne i nie wszystko, co myśl ludzka ogarnia jest możliwe do wyprodukowania czy kupienia, ale sam umysł, siła woli i wiara w powodzenie, daje wielu ludziom z niepełnosprawnością taki potencjał, jakiego nie posiadają ci, którym w życiu wszystko układa się pomyślnie.

Emancypacja $\mathrm{w}$ odniesieniu do osób z niepełnosprawnością nie jest zwykłym przejawem dążeń do poprawy własnego położenia,

${ }^{31}$ M.L. Wehmeyer, N.W. Garner, The impact of personal characteristics of people with intellectual and developmental disability on self-determination and autonomous functioning, "Journal of Applied Research in Intellectual Disabilities" 2003, nr 16, vol. 4, s. $255-265$.

32 M. Czrepaniak-Walczak, op. cit. 
ale efektem długotrwałego procesu rehabilitacyjnego, działań całego zespołu specjalistów, rodziców, wsparcia społecznego i odpowiedniej infrastruktury ekonomicznej, politycznej, prawnej, społecznej, edukacyjnej, która sprzyja wyzwoleniu się dążeń emancypacyjnych osób dotychczas niekoniecznie w sposób świadomy dyskryminowanych.

Do działań emancypacyjnych nie są jednak zdolne osoby z niepełnosprawnością umysłową, bo takie zachowanie wymaga dojrzałości intelektualnej, emocjonalnej i społecznej, a więc harmonijnego rozwoju całej osobowości, czego nie możemy oczekiwać od osób z niesprawnością intelektualną.

Emancypacja może być traktowana jako jeden z przejawów i efektów rehabilitacji oraz jako przejaw samorealizacji wobec własnej osoby z uwzględnieniem potrzeb innych członków tej samej grupy społecznej. Emancypacja jest wyrazem dążeń autorehabilitacyjnych umacniających własną kondycję psychiczną i nadających sens własnemu istnieniu.

Zastanawiające jest tylko, czy potrzebne jest tworzenie nowej nazwy dla działań, które i tak są obecne w procesie rehabilitacji realizowanym przez wielu specjalistów - nie tylko pedagogów. Najważniejszy jest sam człowiek, a nie to, w jakie ramy teoretyczne czy pojęciowe ubierzemy wysiłek skierowany na konkretną osobę, bo i tak program rehabilitacyjny realizowany jest $\mathrm{w}$ stosunku do jednostki i do jej konkretnej sytuacji jest dopasowywany. Wobec ogromnej ilości już istniejącego nazewnictwa warto raczej pomyśleć nad tym jak uporządkować dotychczasową terminologię, aby dla interdyscyplinarnego zespołu rehabilitacyjnego była jednoznaczna, zamiast wprowadzać dodatkowy chaos terminologiczny.

Bibliografia

Cattell H.E.P., Mead A.D., The Sixteen Personality Factor Questionnaire (16PF), [w:] The SAGE Handbook of Personality Theory and Assessment: Vol. 2 - Personality Measurement and Testing, red. G.J. Boyle et al., Sage, Los Angeles 2008. 
Cattell R.B., The Scientific Analysis of Personality, MD: Penguin, Baltimore 1965.

Czrepaniak-Walczak M., Pedagogika emancypacyjna, GWP, Gdańsk 2006.

Doroszewska J., Pedagogika specjalna, Ossolineum, Wrocław1989.

Kennedy M., Wonnacot J., Neglect of disabled children, [w:] Child neglect. Practice issues for health and social care, red. J. Taylor, B. Daniel, Jessica Kingsley Publishers, London - Philadelphia 2005.

Konarska J., Psychospoteczne korelaty poczucia sensu życia a niepetnosprawność, GWSP, Mysłowice 2002.

Konarska J., Niepetnosprawność dziecka jako sytuacja kryzysowa w rodzinie, [w:] Kryzys, interwencja i pomoc psychologiczna. Nowe ujęcia i możliwości, red. D. Kubacka-Jasiecka, K. Mudyń, Wydawnictwo A. Marszałek, Torun 2003.

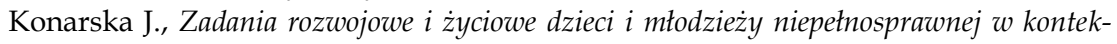
ście dynamizowania osobistych oraz środowiskowych zasobów, [w:] Dzieci i młodzież ze specjalnymi potrzebami edukacyjnymi w realizacji zadan rozwojowych, red. B. Witkowska, K. Bidziński, P. Kurtek, Wydawnictwo Uniwersytetu Humanistyczno-Przyrodniczego, Kielce 2010.

Konarska J., Wsparcie rodziców w ramach wczesnej interwencji na terenie Polski - raport $z$ badań, [w:] Profilaktyka i terapia z perspektywy wspótczesnej pedagogiki, red. J. Szempruch, Z. Zbróg, A. Ratajek, Wydawnictwo Uniwersytetu Humanistyczno-Przyrodniczego, Kielce 2011.

Konarska J., Kryzysy młodzieży z niepetnosprawnościa versus kryzysy rodziców, [w:] Kryzysy $i$ ich przezwyciężanie. Problemy interwencji i pomocy psychologicznej, red. D. Kubacka-Jasiecka, K. Mudyń, Wydawnictwo A. Marszałek, Toruń 2014.

Konarska J., Zdolność do autorehabilitacji jako konsekwencja wcześniejszych zabiegów wychowawczo-rehabilitacyjnych, "Annales” 2014a, vol. XXVII, Nr 1, sectio J. UMS, Lublin.

Kosakowski Cz., Podmiotowość $i$ autorewalidacja w pedagogice specjalnej, „Roczniki Pedagogiki Specjalnej" 1996, t. 7.

Kostyłlo H., Przestanie "pedagogiki uciśnionych" Paula Freire, „Forum Oświatowe” 2011, nr 2(45).

Krause A., Wspótczesne paradygmaty pedagogiki specjalnej, Impuls, Kraków 2010.

Krause A., Teoretyczne inspiracje pedagogiki specjalnej - pedagogika emancypacyjna, [w:] "Studia Edukacyjne“, 2013, nr 28.

Kuryłowicz M., Wiliński A., Rzymskie prawo prywatne, Zakamycze, Kraków 1999.

Lipkowski O., Pedagogika specjalna. Zarys, PWN, Warszawa 1979.

Pedagogika rewalidacyjna, red. A. Hulek, PWN, Warszawa 1980.

Podgórska-Jachnik D., Głusi. Emancypacje, WSP, Łódź 2013.

Popielski K., Noetyczny wymiar osobowości. Psychologiczna analiza poczucia sensu życia, RW KUL, Lublin 1993.

Przybylski S., Refleksje nad barierami występującymi przy wdrażaniu integracji osób niepetnosprawnych w Polsce na początku nowego tysiaclecia, [w:] Integracja osób nie- 
petnosprawnych w edukacji i interakcjach społecznych, red. Z. Kazanowski, D. Osik-Chudowolska, Wydawnictwo UMCS, Lublin 2003.

Reflection of Inclusive Education of the 21st Century in Correlative Scientific Field, red. V. Lechta, B. Kudláčová, Peter Lang International Academic Publishers. Frankfurt am Main 2013.

Sekułowicz M., Wypalanie się sił rodziców dzieci z niepetnosprawnością, DSW, Wrocław 2013.

Sękowska Z., Pedagogika specjalna, Wydawnictwo UMCS, Lublin 1978.

Stownik jezzyka polskiego PWN, www.spj.pwn.pl [31.10.2015].

Szumski G., Integracyjne ksztatcenie niepetnosprawnych, APS, Warszawa 2006.

Śliwerski B., Współczesne nurty i teorie wychowania, Impuls, Kraków 2001.

The Routledge Companion to Feminism and Postfeminism, red. S. Gamble, London New York 1999.

Twardowski A., Sytuacja rodzin dzieci niepetnosprawnych, [w:] Dziecko niepetnosprawne w rodzinie, red. I. Obuchowska, WSiP Warszawa 1991.

Twardowski A., Oddziatywania rodziców blokujące rozwój autonomii u dzieci upośledzonych umystowo, [w:] Społeczeństwo wobec autonomii osób niepetnosprawnych, red. W. Dykcik, Eruditus, Poznań 1996.

Tylewska-Nowak B., Autonomia osób z głębszą niepetnosprawnościa intelektualna w opinii wybranych grup społecznych, UAM, Poznań 2001.

Wehmeyer M.L., Garner N.W., The impact of personal characteristics of people with intellectual and developmental disability on self-determination and autonomous functioning, "Journal of Applied Research in Intellectual Disabilities" 2003, nr 16 vol. 4.

Witkowski L., O stanie i problemach recepcji pedagogiki radyklanej w Polsce, [w:] Edukacja $i$ sfera publiczna, idee $i$ doświadczenia pedagogiki radykalne, red. H.A. Giroux, L. Witkowski, Impuls, Kraków 2010. 